\title{
Tempering the temporary: Improving thermal safety and comfort in relief shelters
}

\author{
Shreejaya Tuladhar ${ }^{1}$, Joëlle Jahn ${ }^{2}$, Holly Samuelson ${ }^{3}$ \\ ${ }^{1}$ Page Southerland Page, Houston, USA \\ ${ }^{2}$ WSP, Boston, USA \\ ${ }^{3}$ Graduate School of Design, Harvard University, Cambridge, USA
}

\begin{abstract}
Despite guidelines encouraging climate responsive designs, post-disaster/conflict temporary shelters are frequently deployed across substantially different climates, resulting in anecdotes of unbearable interior temperatures. Therefore, in order to test their climateappropriateness, we performed thermal simulations of fourteen of the most common shelter types, testing these designs in thirteen different climate zones. Evaluating these shelters based on adaptive thermal comfort threshold temperatures proved inadequate as interior operative temperatures frequently far exceeded this threshold. Therefore, we proposed using $35^{\circ} \mathrm{C}\left[95^{\circ} \mathrm{F}\right]$ and $12^{\circ} \mathrm{C}\left[54^{\circ} \mathrm{F}\right]$ for the upper and lower health-risk temperature thresholds to evaluate thermal safety. In several cases, the simulations identified interior conditions outside these limits, which could pose health risks to occupants, especially to vulnerable populations, e.g. the elderly, sick and children. We then used thermal simulation to test improvements to temporary shelter design and synthesize new designs, and to suggest quantitative guidelines to improve thermal safety.
\end{abstract}

\section{Introduction}

A temporary shelter is meant as an early recovery shelter until a more permanent shelter solution is found. It is actually the second phase of a three-phase process for resettlement commonly used (IFRC, 2011). The first phase is an emergency shelter (e.g. a tent or tarp), which is a life-preserving intervention meant to last 1-2 weeks. Permanent re-construction marks the final phase. Falling between these phases, temporary shelters are intended to last 2 years. Alternatively, transitional shelters can be built by incrementally combining the three phases.

Internationally recognized shelter guidelines (Sphere, 2011 and IOM, 2012) aim to set a universal building code for temporary shelters. They set occupancy limits and prohibit indoor combustion-based cooking. When it comes to climate, they advocate for locally sourced, climate-specific shelter design solutions, but they are vague and devoid of prescriptive quantitative metrics for designers and builders. No thermal comfort or thermal safety standards are set.

Despite being designed for a particular climate, similar temporary shelters are commonly deployed around the world. Annual case study reports on shelter designs (IFRC, 2011 and IFRC, 2013) deployed/supported by
International Red cross shows multiple cases of replication of similar shelter design in various climate zones and locations. This trend has seen continuity with UN (United Nations) organizations partnering with the IKEA foundation to develop the Better Shelter (Better Shelter, 2015) - a flat packed pre-fabricated shelter solution to be deployed globally. According to interviews with organizations involved in this sector, current temporary shelter responses are built under time and cost constraints without comfortable thermal conditions as a high priority. One interviewee witnessed expensive prefabricated shelters that were helicoptered into a remote, high-altitude site and later abandoned in the winter due to unbearable interior temperatures.

In this research, we used thermal simulation to test the thermal comfort and safety of fourteen of the most common temporary shelter designs in use today. We tested each one in its originally intended climate and in thirteen other global climate zones (ASHRAE 1-5) (ASHRAE, 2013). Currently there is no agreed-upon standard for upper limit in indoor temperature for thermal safety (Nicols, 1995; Holmes et al, 2016). We propose using $35^{\circ} \mathrm{C}\left[95^{\circ} \mathrm{F}\right]$ and $12^{\circ} \mathrm{C}\left[54^{\circ} \mathrm{F}\right]$ for the upper and lower "health risk" temperature threshold to evaluate thermal safety of the temporary shelters. The upper limit was based on ceiling fans being less effective at this temperature (World Health Organization Europe, 2009) and statistical data on mortality rate during heat waves (World Health Organization Europe, 2009). The lower limit is based on data suggesting that vulnerable population, i.e. the elderly, sick and small children, are susceptible to cardiovascular problems and strokes in sustained conditions below this temperature (Collins, 1996).

Our results showed not only that the interior temperatures exceeded the threshold for ASHRAE-55 adaptive thermal comfort (ASHRAE, 2010) for more than half the year but also that they cross the above-mentioned health risk limits frequently. The internal temperatures exceeded the adaptive thermal comfort threshold by a huge margin indicating a real need for a new metric and threshold limits in order to compare performance and evaluate thermal safety. We synthesized the results data to produce a set of design guidelines to improve interior thermal conditions in existing temporary shelters as well as redesign the shelters. 


\section{Methodology}

Fourteen temporary shelters were selected from the International Federation of Red Cross and Red Crescent post-occupancy reports on post-disaster shelters (IFRC, 2011 and IFRC, 2013). The shelters, described in Table 1, each have single layer assemblies. In particular, most of the roofs consist of a single layer of CGI (corrugated galvanized iron) - corrugated sheet metal roof with the metal exposed to the interior. The walls consist of a single layer of plastic/tarp, plywood, or woven bamboo panels, or masonry in limited cases. There is little thermal mass (except for shelters with masonry walls) and no insulation. There were small window openings, which were non-glazed. The costs range from $\$ 500$ to $\$ 5000$.

Table 1: Temporary Shelter description.

\begin{tabular}{|c|c|c|c|}
\hline $\begin{array}{l}\text { Shelter } \\
\text { name }\end{array}$ & $\begin{array}{l}\text { ASHRAE } \\
\text { climate } \\
\text { zone } \\
\text { (original) }\end{array}$ & $\begin{array}{c}\text { Köppen } \\
\text { climate } \\
\text { zone }\end{array}$ & Construction \\
\hline $\begin{array}{l}\text { Afghani- } \\
\text { stan plastic } \\
\text { shelter } \\
\end{array}$ & $5 \mathrm{~B}$ & Dfb & $\begin{array}{c}\text { Tarp/plastic wall \& } \\
\text { roof }\end{array}$ \\
\hline $\begin{array}{c}\text { Ethiopia } \\
\text { Better } \\
\text { shelter } \\
\end{array}$ & $1 \mathrm{~B}$ & Bwh & plastic wall \& roof \\
\hline $\begin{array}{l}\text { Haiti Steel } \\
\text { frame }\end{array}$ & $1 \mathrm{~A}$ & Aw & $\begin{array}{c}\text { Tarp/plastic wall \& } \\
\text { roof }\end{array}$ \\
\hline $\begin{array}{c}\text { Haiti } \\
\text { Plywood }\end{array}$ & $1 \mathrm{~A}$ & Aw & $\begin{array}{c}\text { Plywood - wall } \\
\text { CGI - roof }\end{array}$ \\
\hline $\begin{array}{c}\text { Indonesia } \\
\text { timber }\end{array}$ & $1 \mathrm{~A}$ & Af & $\begin{array}{l}\text { Matted palm - wall } \\
\text { Palm fiber - roof }\end{array}$ \\
\hline $\begin{array}{l}\text { Bangladesh } \\
\text { roof attic }\end{array}$ & $1 \mathrm{~A}$ & Af & $\begin{array}{c}\text { Bamboo - wall } \\
\text { CGI -roof }\end{array}$ \\
\hline Peru timber & $1 \mathrm{~B}$ & Bwh & $\begin{array}{c}\text { Timber - wall } \\
\text { CGI - roof }\end{array}$ \\
\hline $\begin{array}{l}\text { Philipines } \\
\text { raised floor }\end{array}$ & $1 \mathrm{~A}$ & Af & $\begin{array}{c}\text { Bamboo - wall } \\
\text { CGI -roof }\end{array}$ \\
\hline $\begin{array}{l}\text { Philipines } \\
\text { masonry }\end{array}$ & $1 \mathrm{~A}$ & Af & $\begin{array}{c}\text { brick \& plywood } \\
\text { wall } \\
\text { CGI -roof }\end{array}$ \\
\hline $\begin{array}{l}\text { Pakistan } \\
\text { masonry }\end{array}$ & $2 \mathrm{~A}$ & Cfa & $\begin{array}{c}\text { Brick - wall } \\
\text { Clay tile - roof }\end{array}$ \\
\hline $\begin{array}{l}\text { India A- } \\
\text { frame }\end{array}$ & $1 \mathrm{~B}$ & Bwh & $\begin{array}{c}\text { Brick - wall } \\
\text { CGI - roof }\end{array}$ \\
\hline $\begin{array}{c}\text { Sri Lanka } \\
\text { masonry }\end{array}$ & $1 \mathrm{~A}$ & Af & $\begin{array}{c}\text { Brick - wall } \\
\text { CGI - roof }\end{array}$ \\
\hline Nepal vault & $3 \mathrm{~A}$ & Cfa & CGI - wall \& roof \\
\hline $\begin{array}{c}\text { Nepal } \\
\text { masonry }\end{array}$ & $3 \mathrm{~A}$ & Cfa & $\begin{array}{c}\text { Brick - wall } \\
\text { CGI - roof }\end{array}$ \\
\hline
\end{tabular}

Because shelters are often deployed in a variety of climates (IFRC, 2011 and 2013; Better Shelter, 2015), we evaluated the performance of each shelter in different climate zones to determine its suitability or lack thereof. We simulated each shelter for one year, using a typical meteorological weather file for a representative site, both representing the originally designed-for climate zone and each ASHRAE climate zone from 1A to 5C (ASHRAE, 2010). Colder climate zones (Climate zone 5 and up) were not selected, since for these conditions prefabricated permanent shelters perform better (Manfield, 2000).
Thermal simulations were performed using the US Department of Energy's EnergyPlus (DOE, 2015) simulation engine, via the Honeybee interface (Rousdari M.S and Mackey C., 2017), a plug-in for Grasshopper (McNeel, 2017), a visual scripting plugin for the Rhinocerous 3D modeling software (McNeel, 2017). The shelters were modelled as a single zone as the shelters typically had a single one small room, $3-4 \mathrm{~m}$ in width and not more than $6 \mathrm{~m}$ in length. There were no active HVAC systems or fans used in any of the shelters, which also did not have indoor kitchens, as per shelter standards.

The occupancy of the shelter was modeled to meet the minimum shelter standard of $3.5 \mathrm{~m}^{2}\left[37.67 \mathrm{ft}^{2}\right]$ ) of floor area per person $\left(0.25\right.$ persons $/ \mathrm{m}^{2}\left[0.0232 \mathrm{ft}^{2}\right]$ ) (Sphere, 2011). No lighting, equipment and plug loads were added because the shelters have no access to the electric grid.

Because of the high occupant loads and low thermal mass (heat capacity) in most of the shelters, as well as small openings it was assumed that the occupants would leave the windows open when indoor air temperatures were above $18^{\circ} \mathrm{C}\left[64^{\circ} \mathrm{F}\right]$. Analytical evaluation of natural ventilation was done using equations for buoyancy-driven ventilation which showed that the openings did not provide sufficient natural cooling in humid climates, resulting in overheating by $10^{\circ} \mathrm{C}\left[18^{\circ} \mathrm{F}\right]$ just by occupancy loads. Impact of insect screen on natural ventilation was also studied.

We performed a sensitivity analysis on infiltration rates. EnergyPlus calculates infiltration in a zone based on the air leakage rate of the envelope, as well as the difference betweenindoor and outdoor temperature and wind ( $\mathrm{Ng}$ and Emmerich, 2014).Using the ASHRAE recommended air leakage rate for an average $\left(0.0003 \mathrm{~m}^{3} / \mathrm{s}[0.63 \mathrm{cfm}]\right.$ per $\mathrm{m}^{2}$ exposed area) and leaky building $\left(0.006 \mathrm{~m}^{3} / \mathrm{s}[1.27 \mathrm{cfm}]\right.$ per $\mathrm{m}^{2}$ exposed area) produced a difference of $\sim 1^{\circ} \mathrm{C}$ indoors on a cold week and $0.5^{\circ} \mathrm{C}\left[<1^{\circ} \mathrm{F}\right]$ on a hot week in a shelter in climate zone 3A. For the remaining simulations, the infiltration rate was set at $0.006 \mathrm{~m}^{3} / \mathrm{s}[1.27 \mathrm{cfm}]$ per $\mathrm{m}^{2}$ of exposed area, as recommended for leaky buildings (ASHRAE, 2001).

Although the initial goal of the research was to evaluate adaptive thermal comfort, the resulting extreme hot and cold interior temperatures required a modified objective. Based on the results, the goal of the research was modified to include analyzing thermal-safety, using the temperature thresholds listed above, then improving thermal comfort as far as possible.

Based on the analysis of the shelters' performance, redesign strategies were formulated and simulated. Based on sourcing of building materials they were essentially divided into i) an on-site shelter using locally sourced materials, which included retrofit/modification of the previously studied shelter design, as well as a new design, and, ii) an off-site, prefabricated shelter for scenarios needing quick deployment or for locations lacking locally sourced materials. Criteria for our material selections were affordability and ease of construction. Since, in postdisaster and conflict scenarios there may be a scarcity of building materials.

\section{For Retrofit/Modification}


The A-frame shelter was chosen as a test case for design improvement and modification, because of its benefits, such as low material cost, ease of construction, and its earthquake/high-wind resistant structure. ASHRAE climate zone 3A using Kathmandu, Nepal was our weather file. Various passive strategies were explored in order to achieve thermal safety such as the addition of thermal mass (heat capacity), a passive solar roof pond, sod, a shaded roof, or insulation using natural materials. In some cases, different parameters for the strategy (e.g. thicknesses of insulation) were explored. For natural insulation, rice hulls, an agricultural by-product of rice production, was chosen for its thermal resistance, vermin and fireproof properties. Its thermal properties (e.g. thermal conductivity $=0.5 \mathrm{~W} / \mathrm{m}-{ }^{\circ} \mathrm{K}$ ) used for simulation were taken from existing literature (Gradillas,2015).

A passive solar technique for storing daytime solar gain was simulated with a glazed opening on the roof, which at night, was covered with a movable straw mat insulation to prevent heat loss. This was modeled for the simulation via dynamic shading. Water barrels exposed to the sun through the roof glazing were added on the far wall to increase the thermal mass of the shelter. Figure 1 shows the strategy of rice hull insulation, passive solar with added thermal mass, and movable insulation for roof glazing.

Roof strategies simulated were the roof pond, sod roof and a shaded roof. The roof pond strategy involves bags of water stored on the roof, which use the high heat capacity of water coupled with radiative heat loss to the night sky for cooling or storing daytime solar heat for warming. During cold days, the bags are exposed to the sun then covered with a movable insulation (e.g. straw mat rolls) at night.
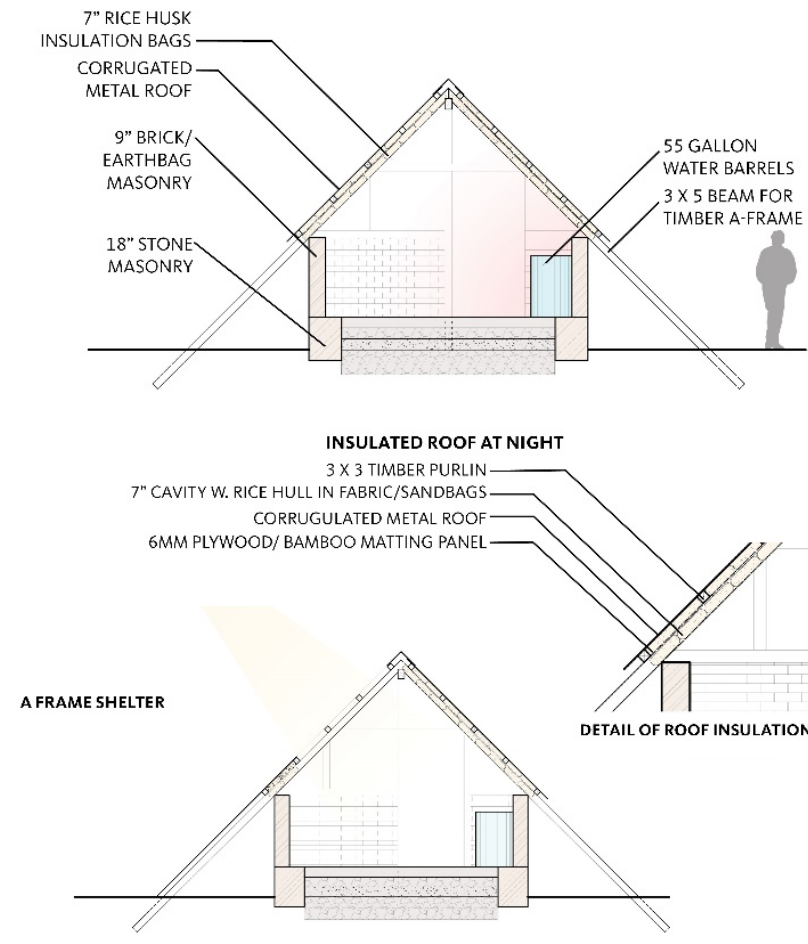

DAYTIME PASSIVE SOLAR HEAT GAIN

Figure 1: Retrofitted/modified A-frame shelter.

The heat stored in the water bags transfers through the Proceedings of the 16 th IB Ith interior. The daytime Rome, Italy, Sept. 2-4, 2019 exposed/nighttime insulated process can be reversed to provide cooling in summer where water loses heat to the nighttime sky. The movable straw insulation was modeled as an external dynamic shading device scheduled to be deployed at night.

To simulate a shaded roof, a plastic sheeting or canvas was used to shade the CGI roof. For the sod roof, i.e. soil on top of the CGI roof, thermal properties of typical soil (IES, 2012) were used and the assembly was modeled as an additional layer of material in addition to the CGI metal roof. It should be noted that the simulation did not take into account the additional evapo-transpirational cooling effect the moisture content of soil could provide.

\section{Off-site prefabricated shelter solution}

Prefabricated shelters help support places where local material sourcing is not possible or sustainable. Evaluation of the existing shelters (see results) showed that insulation would be necessary as the outdoor temperature frequently exceeded the set thermal safety limits and the shelters lacked active heating/cooling. We proposed a lightweight multi-layered radiant hollow-core insulation with strategically spaced air gaps between Mylar layers based on previous research (Craig, 2013). This air gap prevents the air from transferring heat through conduction.

Also solar heat gain was a major factor in indoor overheating thus, solar shading was crucial to the solution. A prefabricated shelter, Better Shelter (Better Shelter, 2015) was used for baseline comparison.

Here, we propose a three-phase incremental construction approach, as described in the Introduction, and designed a shelter meant to avoid overheating due to solar gain. It also adds shaded semi-outdoor spaces, increasing the habitable area of the shelter. Phase 1 involves assembling the main shelter. In Phase 2, a roof shade is added with sufficient overhang to create portico spaces and shade the walls. In Phase 3, screen walls are added on the east and west side to create additional semi-interior space. Opening sizes were chosen using hand calculations to provide more natural ventilation than the baseline.

\section{On-site locally sourced material redesign}

We designed a shelter using locally sourced materials and labor for hot and humid climates, shown in Figure 2. Based on the superior performance of the existing shelter with an attic (see results), we included an attic space.

It acts as a buffer space between the CGI metal roof and the occupied space. It also allows for the storage of goods. The walls can be made out of low lightweight thermal mass materials. To improve natural ventilation from existing shelters suitable for a hot humid climate, four windows and a large vent at the top on the north facade were included.This shelter is also uses the three phase incremental approach. 


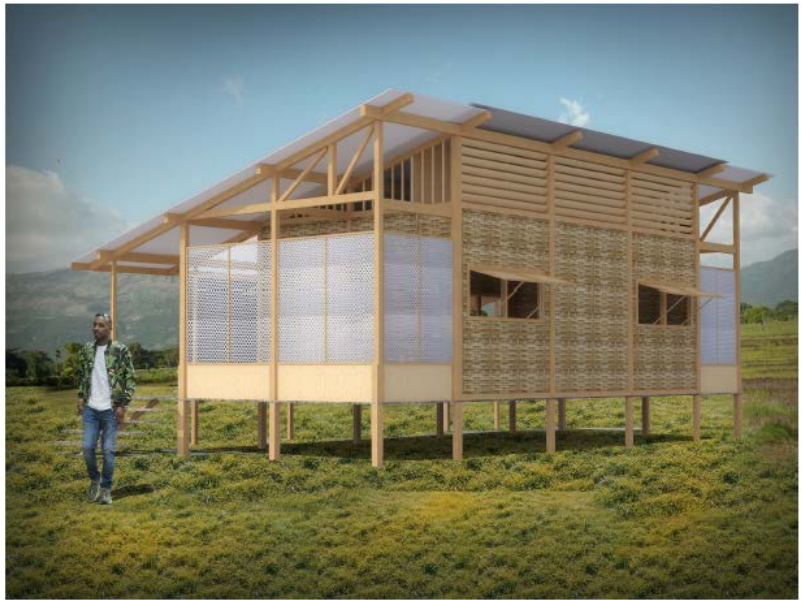

Figure 2: Rendering of On-site solution.

Physical hot-box tests for conductivity were performed on alternative insulations without established standard values. Tests were done on shredded denim and hollow core, multi-layered radiant Mylar insulation. The resultant conductivity values were used during simulations.

\section{Results}

The results showed that the interior temperatures farexceeded the ASHRAE-55 adaptive thermal comfort threshold temperature for more than half the year in most cases. Figure 3 summarizes the percentage of the year in which adaptive thermal comfort conditions were met/unmet. However, this common simulation metric proved misleading, because while some shelter designs had similar unmet hours, the extent to which the interior operative temperature exceeded the adaptive comfort threshold varied greatly.

Therefore, we proposed a metric to better evaluate the performance of the shelters, specifically Hot and Cold Degree-Hours, the ${ }^{\circ} \mathrm{K}$ above or below the adaptive comfort threshold calculated for each hour and then summed over the year. The simulation results, shown in Figure 4, showed that interior thermal conditions were far from adaptive comfort conditions. In fact, they reached health-risk temperatures.

When we ran simulations to improve natural ventilation, opening (windows or doors) of at least $5 \%$ of facade area and $1 \mathrm{~m}$ height difference between its center resulted in reduction of indoor air temperature $3^{\circ} \mathrm{C}$ in hot humid climates. This also resulted in hourly air change rate $(\mathrm{ACH})$ of over at least 20 calculated using analytical equations.

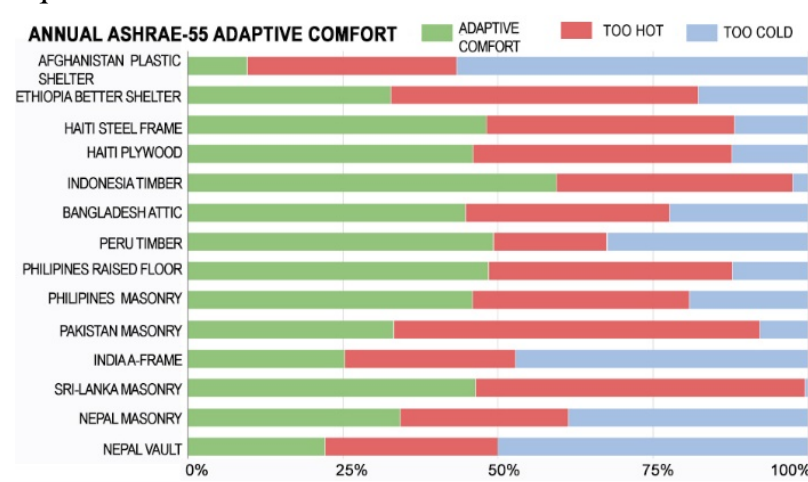

Figure 3: 14 shelter thermal comfort summary.

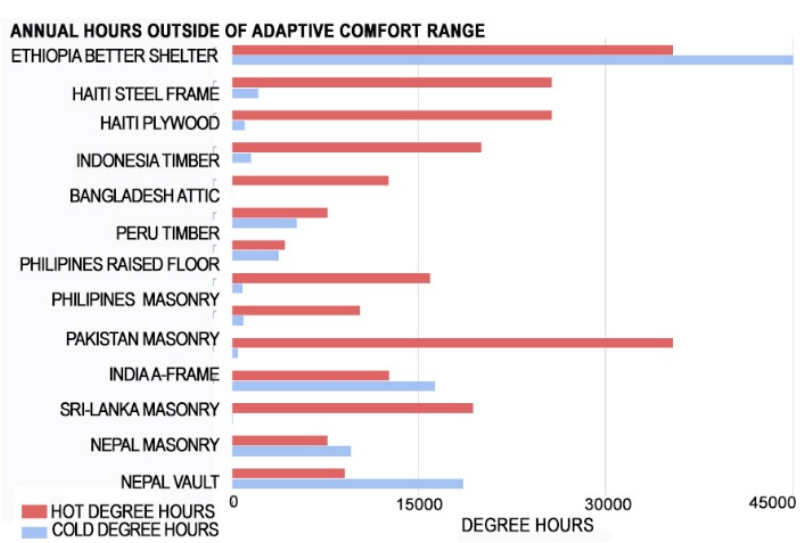

Figure 4: Degree hours above/below thermal comfort.

The internal operative temperatures mirrored outdoor temperatures except at mid-day. This can be explained by the shelters having minimal thermal mass and insulation. During mid-day, the temperatures soared extremely high due to heat gain from the midday sun. The sun-baked metal roof, exposed to the interior, explains the extremely hot interior operative temperatures. This meant that the indoor conditions were worse than outdoors, as shown in Figure 3 for the hottest week.

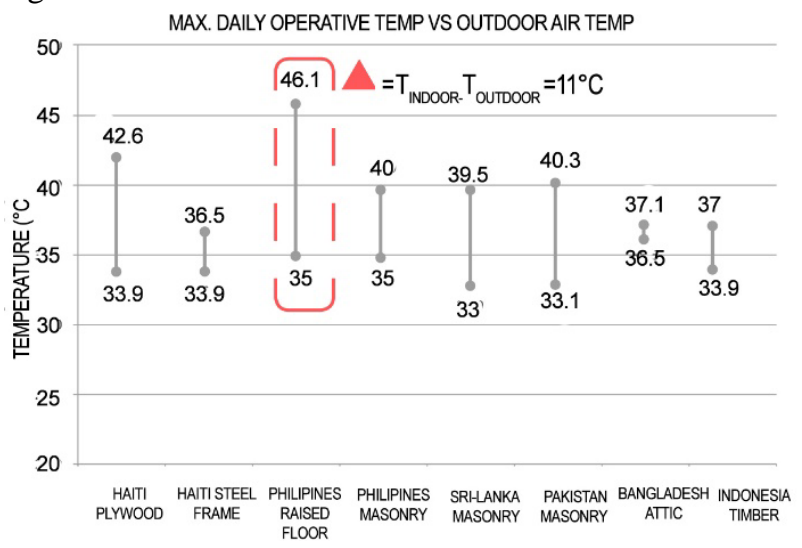

Figure 5: Temperature differential on hottest week.

Figure 6 shows the simulated performance of the shelters during the hottest week. One can see that the shelters suffered from overheating, reaching the "health risk" range of $35^{\circ} \mathrm{C}\left[95^{\circ} \mathrm{F}\right.$, which was due, in part, to solar gains. In some cases operative temperatures reached 11 ${ }^{\circ} \mathrm{C}\left[20^{\circ} \mathrm{F}\right]$ hotter than the outdoor air temperature as illustrated in Figure 5.

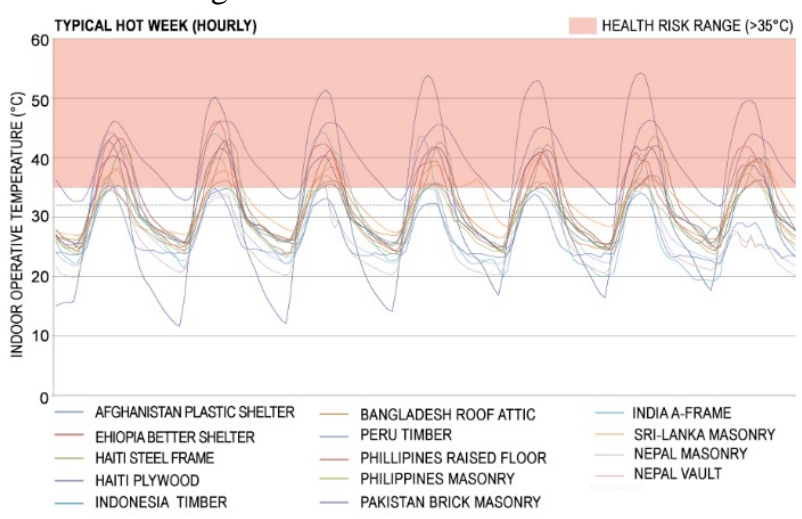

Figure 6: Operative temp. of shelters, hottest week.

Figure 7 illustrates the performance of the shelters in their original and reference climate zones in a matrix format. Indoor temperatures fell outside the adaptive thermal 
comfort zone for the majority of hours, in all but one case. In the masonry shelters, the high thermal mass proved to be effective in colder climates.

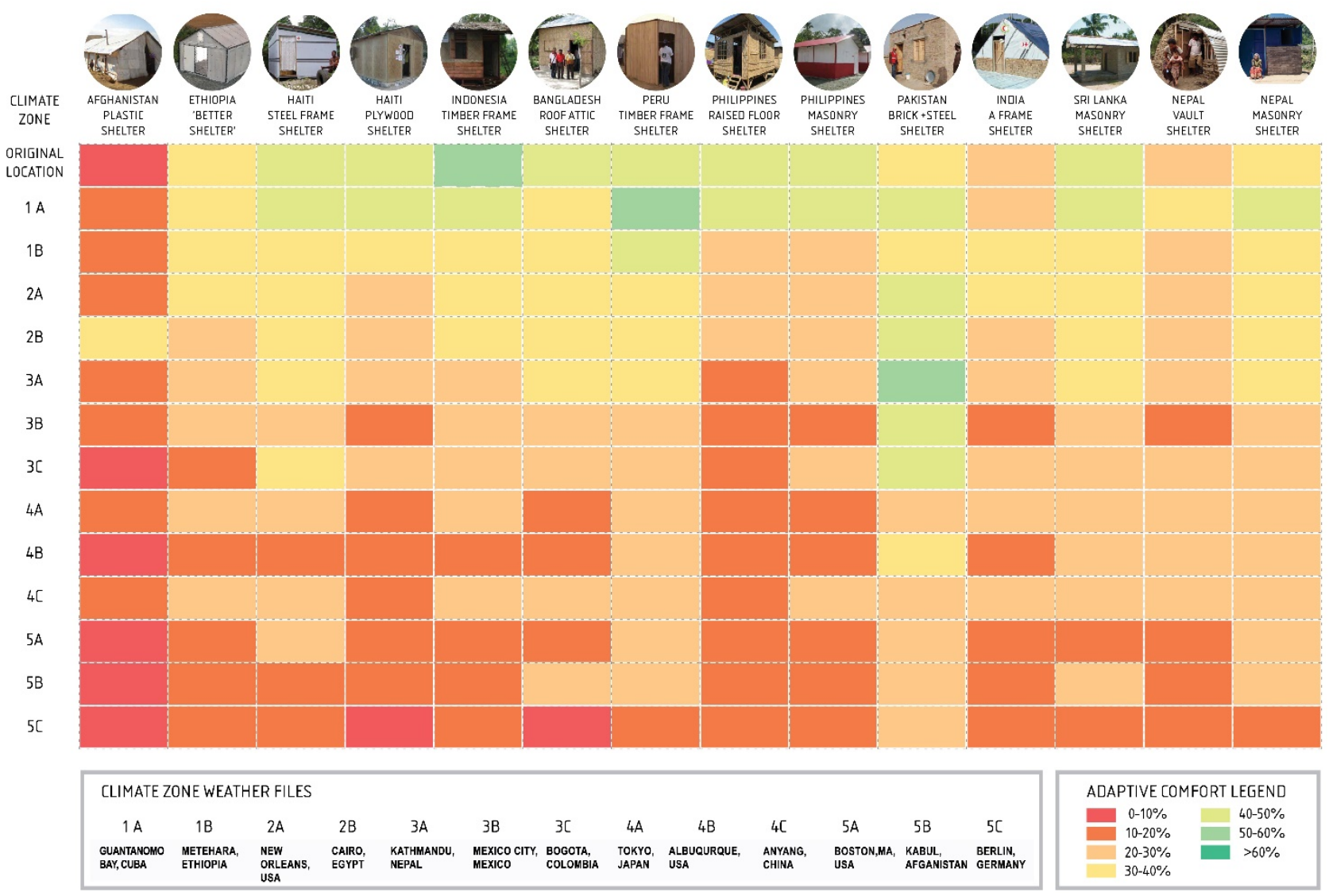

Figure 7: Annual adaptive comfort shelter matrix.

Figure 8 shows the simulated performance in the coldest week with the shelters in the cooler climates dipping below the "health risk" zone of $12^{\circ} \mathrm{C}\left[54^{\circ} \mathrm{F}\right]$. The internal operative temperatures of the shelters reached the "health risk" zone during the hottest and coldest weeks of a typical year. Internal temperatures mirrored outdoor temperatures except at mid-day. The interior condition was much better in the shelter with ceramic tile roofing. Excessive heat gain was also eliminated in the shelter design that had a metal roof but with an attic storage space, intended for storage. This attic space acted as a buffer space and the presence of a ceiling meant that the occupants were not directly exposed to the metal roof.

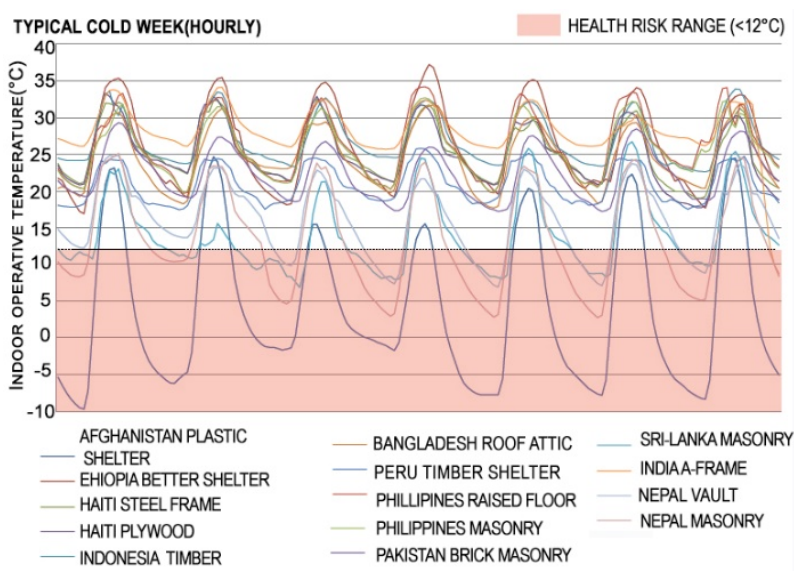

Figure 8: Operative temp. of shelters, Coldest week.
The lessons learned from the analysis were as follows. 1) The metal roof, if used, should not be directly exposed to the occupants and ideally be insulated and/or separated by an attic buffer zone. 2) Most of the heat gain was from solar hence an effective shading strategy would greatly cut down heat gain. 3) Walls also need to be insulated. 4) The addition of thermal mass proved to be effective. 5) Finally, the shelters' small openings did not provide adequate natural cooling. Providing additional ventilation with would flush away-overheated interior air. Openings sized at least $5 \%$ of facade area with $1 \mathrm{~m}$ [3.3ft] center height difference is a reasonable airflow preventing excessive heat buildup. Based on the lessons learned from the previous simulation exercise three design response strategies were explored

\section{Retrofit strategy}

Using Passive solar techniques with the addition of water barrels for thermal mass along with roof insulation, the indoor conditions almost reached comfort conditions of $18^{\circ} \mathrm{C}$. The simulations showed diminishing returns for addition of more water as thermal mass equivalent to 3" [75mm] thick water wall. We also tested multiple roof redesign strategies, as described further. Results for insulation thickness are summarized in Figure 8. Figures 9 and 10 show results of different roof strategies with various thicknesses. 


\section{Roof insulation}

We simulated the addition of different thicknesses of rice hull insulation in the roof, and the results are shown in Figure 9. One can see that the insulation helps the indoor condition avoid the "health risk" threshold of $12^{\circ} \mathrm{C}$, and there are diminishing returns for roof insulation thicknesses greater than 6”.

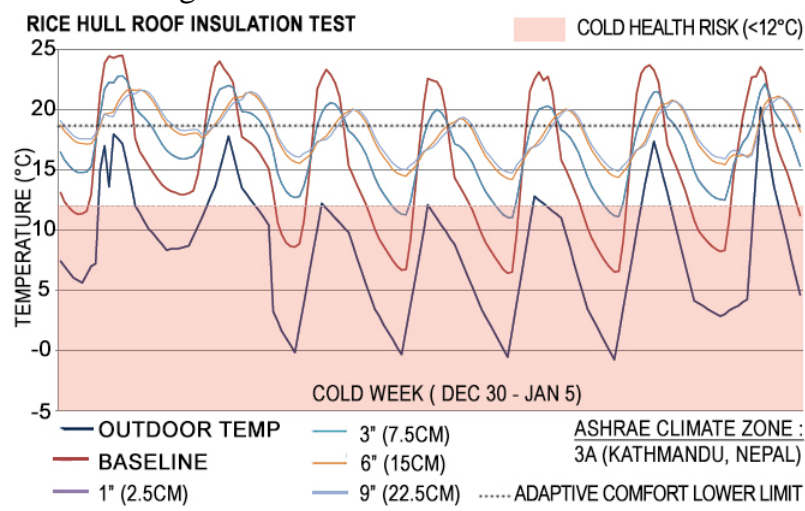

Figure 9: effectiveness of rice hull insulation thickness.

\section{Roof pond}

The roof pond performs significantly better than the baseline of a CGI metal roof. Increase in depth does improve indoor temperatures with diminishing returns above 6" [150mm]. The simulation results showed that the roof pond 6" thick lifts the temperature of the shelter above the cold "health risk" threshold of $12^{\circ} \mathrm{C}\left[54^{\circ} \mathrm{F}\right]$ during cold conditions but could not always achieve the adaptive comfort threshold of around $18^{\circ} \mathrm{C}\left[65^{\circ} \mathrm{F}\right]$.

\section{Sod roof}

The result of the simulations showed that the sod roof is effective at reducing the overheating at mid-day compared to the baseline of just a CGI metal roof. Thickness of 6" [150mm] appears to be the most effective; greater thicknesses provide diminishing returns.

\section{Shaded roof}

Shading the roof also proved to be a very effective solution. In the simulated scenario, a plastic sheeting or canvas was used to shade the CGI roof. Figure11 shows it is more effective than the sod roof of $225 \mathrm{~mm}$ [9”] thickness.

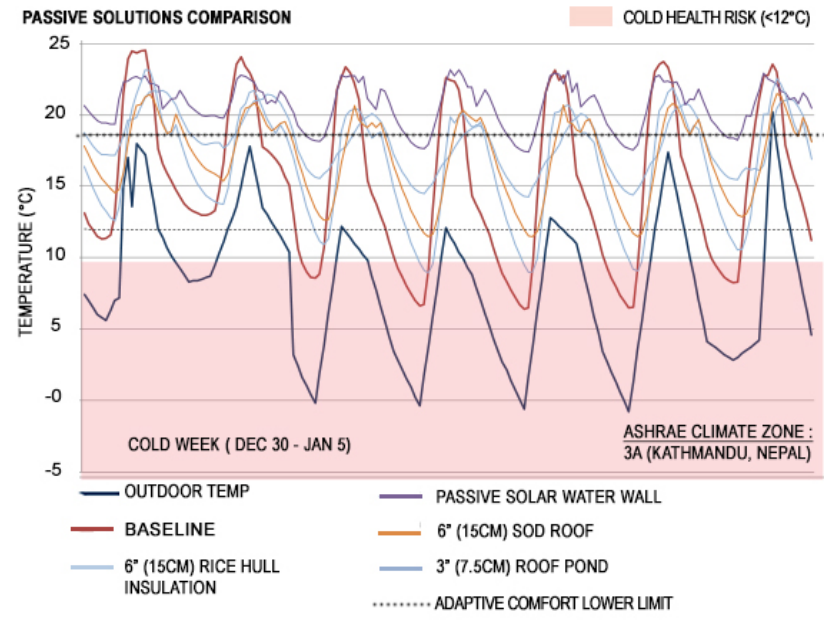

Figure 10: Comparison between passive solutions.

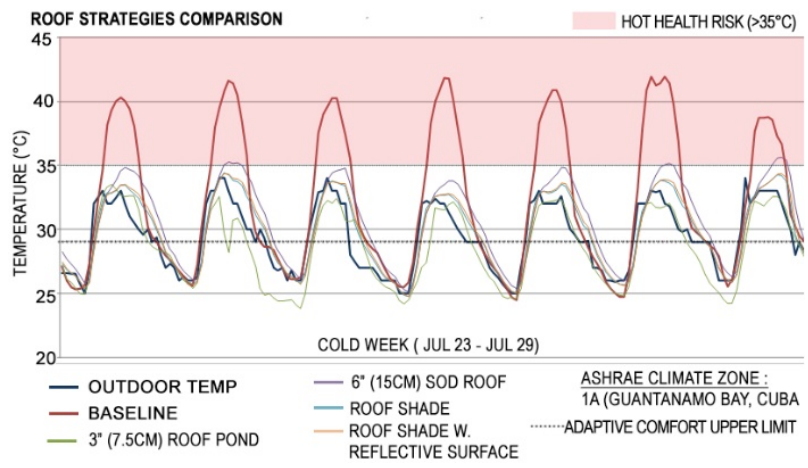

Figure 11: Comparison between roof strategies.

\section{Off-site prefabricated shelter solution}

The conductivity value for the prototype multi-layered radiant hollow-core insulation was determined to be $0.025 \mathrm{~W} / \mathrm{m}-\mathrm{K}$ via physical test. As shown in Figure 13, the simulated performance of this shelter with the prototype insulation and improved ventilation was satisfactory, with operative temperatures falling below the "health risk" temperatures and closely mirroring the outdoor air temperatures.

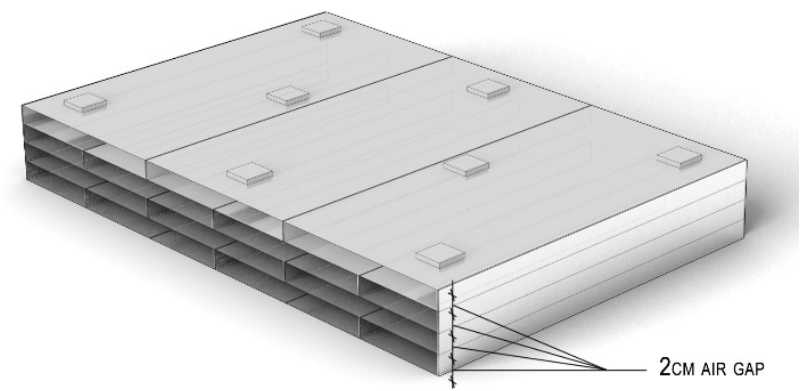

Figure 12: multilayer hollow core Mylar insulation.

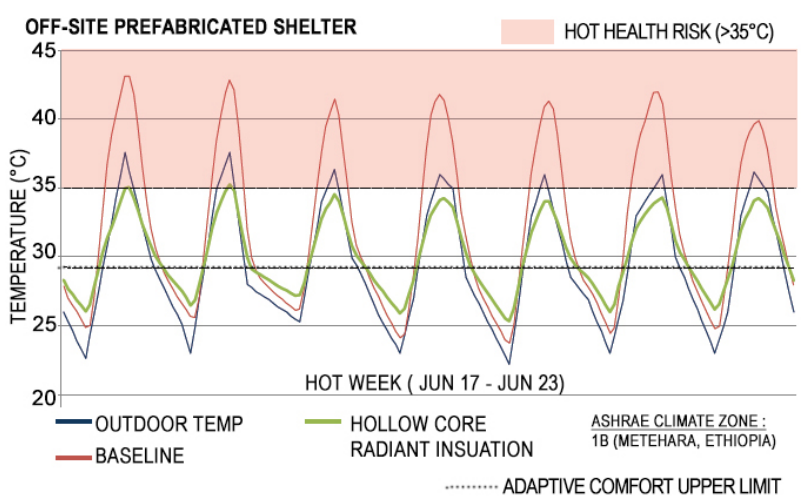

Figure 13: Temperature curve for off-site solution.

\section{On-site locally sourced material redesign}

The "Haiti Plywood" shelter was used for baseline comparison in a hot, humid climate. Figure 14 shows that the simulated performance of this shelter was satisfactory with operative temperatures falling below the "health risk" temperatures and closely mirroring the outdoor air temperatures. 


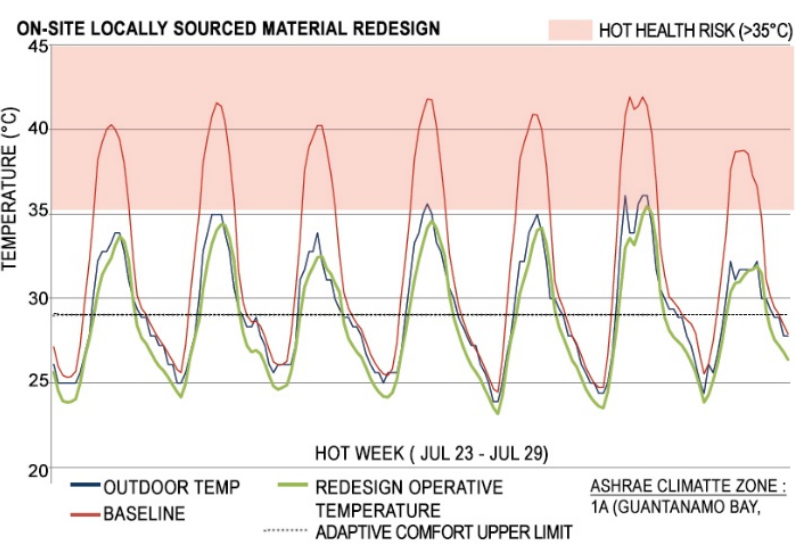

Figure 14: Temperature curve for On-site solution.

\section{Discussion}

According to the simulation results, current postdisaster/conflict temporary shelter designs can fail to ensure thermal comfort, and even safety, especially when deployed to inappropriate climate regions, which is a realworld practice. Furthermore, the investigations performed here used typical, rather than extreme, weather inputs, meaning that real-world conditions could be much worse. Thermal safety and comfort must be prioritized when designing and deploying temporary shelters. Currently, cost followed by ease of construction take priority. Yet, thoughtful design that considers thermal conditions can meet all of these objectives.

This study demonstrated that simulation can be an effective tool to improve thermal safety and comfort in shelter design. Moreover, simulation can be a strategic policy tool to aid decisions to match shelter types to appropriate climates, improving both safety and the effective use of resources.

In the simulations, passive strategies proved to be effective, however they are not very commonly used in existing temporary shelters as compared to permanent shelters of both vernacular and contemporary in nature. Use of simulations could prove to be effective in convincing stakeholders.

In the field of building simulation and building simulation research, we tend to focus on large, complicated, highperformance buildings. Yet, several compelling reasons exist for expanding this focus to include shelter design. First, when dealing with such vulnerable populations and conditions, the stakes are very high. Moreover, it would be an understatement to say that design standards for shelters are "less stringent" then those rules governing most permanent buildings in the developed world.

Also, simulation could possibly be a more effective tool for shelters, because of their simpler nature, e.g. lack of mechanical systems and complicated operation schedules. Finally, temporary shelters may be ideal candidates for using building simulation to test alternative material and design strategies. The shelter's short life span would allow for quick feedback, and lessons learned could be adopted to affordable permanent shelters.

Physical testing of the redesign strategy must be done as a next step to validate the results of this research and further improve it. The result of this simulation study with physical validation can be used as shelter guidelines to ensure thermal safety.

\section{Conclusion}

Commonly used temporary shelters for post-disaster and displaced peoples fail to ensure thermal safety, particular for vulnerable populations. Building simulation can be an effective design and policy tool for shelter solutions that improve thermal safety and comfort. The results shown here can help shed light on matching appropriate shelter designs to different climates.

\section{Acknowledgement}

We would like to thank Prof. Martin Bechthold for his expertise and guidance. We would also like to thank Dr. Salmaan Craig for his suggestions and guidance in implementing his own research into Hollow core insulation. We want to extend our gratitude to Dr. Jonathan Grinham for helping us design and setup our hotbox experiment.

\section{References}

ASHRAE.(2001). Handbook of Fundamental. Table 7, Ch 28

ASHRAE (2013). ANSI/AHSRAE Standard 169-2013 :Climatic Data for Building Design Standards

ASHRAE (2010). ANSI/ASHRAE Standard 552015:Thermal Environmental Conditions for Human Occupancy

All Hands Volunteers. (2015). Nepal Earthquake Response.

Better Shelter. (2015). Better Shelter: A Home Away from Home.http://www.bettershelter.org/wp-content/ uploads/ 2015/12/About_Better-Shelter.pdf

Chang, Y., Wilkinson, S Potangaroa, R, Seville, E. (2010). Resources and Capacity: Lessons Learned from Post-disaster Reconstruction Resourcing in Indonesia, China and Australia. Proceedings from COBRA 2010: The Construction, Building and Real Estate Research Conference of the Royal Institution of Chartered Surveyors

Collins,K.J. (1986). Low indoor temperatures and morbidity in the elderly. Age and Ageing. 15(4), 21220.

Craig, S. (2013). Thermoregulation Using Hybrid Materials. Reading presented in Harvard Graduate School of Design, Cambridge. "In Hollow Core Wall Tutorial"

Crimmins, A., J. Balbus, J.L. Gamble, C.B. Beard, J.E. Bell, D. Dodgen, R.J. Eisen, N. Fann, M.D. Hawkins, S.C. Herring, L. Jantarasami, D.M. Mills, S. Saha, M.C. Sarofim, J. Trtanj, and L. Ziska, Eds (2016). Climate and Health Assessment. U.S. Global Change Research Program.

Das, S., and Smith, S. C. (2012). Awareness as an Adaptation Strategy for Reducing Mortality from Heat Waves: Evidence from Disaster Risk Management Program in India (Vol. WP 72-12). Kathmandu: South Asian Network for Development and Environmental Economics. 
Decker, K. D. (2015). Reinventing the Greenhouse. Low Tech Magazine 12/2015

Department of Energy. (2015).EnergyPlus. Version 8.3.0.

Gradillas, M.S. (2015). Analysis and Design for Thermally Autonomous Housing in ResourceConstrained Communities: A Case Study in Bhuj, India. MIT School of Architecture. Cambridge (USA).

Holmes, S. H., Phillips, T., \& Wilson, A. (2016). Overheating and passive habitability: indoor health and heat indices. Building Research \& Information, 44(1), 1-19.

IFRC. (2011). Transitional Shelters: Eight designs. Geneva: International Federation of Red Cross and Red Crescent Societies.

IFRC (2011). The Sphere Project. International Federation of Red Cross and Red Crescent Societies 4. 243-245.

IFRC. (2013). Post-Disaster Shelter: Ten Designs. Geneva: International Federation of Red Cross and Red Crescent Societies.

IFRC, OCHA. (2015). Shelter After Disaster. Geneva: International Federation of Red Cross and Red Crescent Societies.

Integrated Environmental Solutions Limited. (2012) Apache-Tables User Guide. Version IES Virtual Environment 6.4

International Committee of the Red Cross. (2010). Refugees and Displaced Persons Protected Under Internationl Humanitarian Law. International Committee of the Red Cross. 10/2010

IOM. (2012). IOM Transitional Shelter Guide. International Organization for Migration.

Manfield, P. (2000). A Comparative Study of Temporary Shelters used in Cold Climates. St Johns College, University of Cambridge. Cambridge (UK).

McNeel and Associates.(2012) Rhinoceros 3D. Version 5.

Nicol, J., Humphreys, M., Sykes, O., and Roaf, S. (1995). Standards for Thermal Comfort: Indoor Air Temperature Standards for the 21st Century (1st ed.). London: Taylor and Francis.

Nicol, J., and Humphreys, M. (2002). Adaptive Thermal Comfort and Sustainable Thermal Standards for Buildings. Energy and Buildings,34(6), 563-572.

Ng, L., and Emmerich, S. (2014). Consideration of Envelope Airtightness in Modelling Commercial Buiding Energy Consumption. International Journal of Ventilation, Vol 12 No.4 Mar 2014

Rousdari M.S and Mackey C. (2017). Honeybee.Version 0.0.55.

Sherwood, S. C., and Huber, M. (2010). An Adaptability Limit to Climate Change Due to Heat Stress.

Proceedings of the National Academy of Sciences May 25, 2010107 (21) 9552-9555.

\section{Appendix}

Web link to the document with description of studied temporary shelter design. Temporary Shelter catalogue 